\title{
Environmental Issues and Global Warming
}

\author{
Ranu Chaturvedi
}

\begin{abstract}
Global warming and climate change is looked at in this section of the global issues. Research paper Introduced are some of the effects of climate change. In addition, this section attempts to provide insights into what governments, companies, international institutions, and other organizations are attempting to do about this issue, as well as the challenges they face. Some of the major conferences in recent years are also discussed.
\end{abstract}

\section{INTRODUCTION}

$\mathrm{T}$ HERE is an air of unreality in debating these arcane points when the world is changing in such dramatic ways right in front of our eyes because of global warming.\|... Al Gore

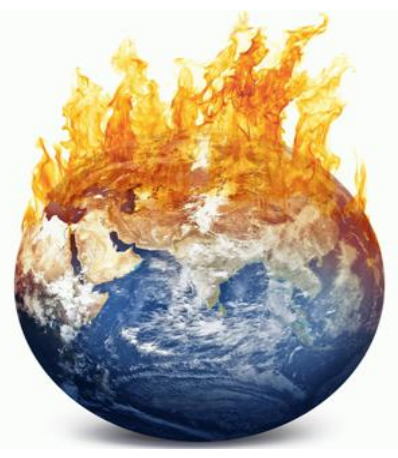

Global warming occurs when carbon dioxide $(\mathrm{CO} 2)$ and other air pollutants collect in the atmosphere and absorb sunlight and solar radiation that have bounced off the earth's surface. Normally, this radiation would escape into space-but these pollutants, which can last for years to centuries in the atmosphere, trap the heat and cause the planet to get hotter.

Global warming induced by the emissions of greenhouse gases is one of the most important global environmental issues facing world today. It is now widely recognised as having significant potential to seriously affect the integrity of our ecosystem and human welfare. Scientists have now been able to reach a broad consensus and provide evidence to suggest that human activities are having influence on global warming. NASA's scientist James Hansen made a radical claim that he was $=99$ percent certain" that the warmer temperatures were the result of fossil fuel consumption.

In the United States, the burning of fossil fuels to make electricity is the largest source of heat-trapping pollution, producing about two billion tons of $\mathrm{CO} 2$ every year. Coalburning power plants are by far the biggest polluters. The country's second-largest source of carbon pollution is the transportation sector, which generates about 1.7 billion tons of CO2 emissions a year.

Ranu Chaturvedi, Department of P.G. Studies and Research in Chemistry and Pharmacy, Rani Durgavati University, Jabalpur-482001 DOI: $10.9756 /$ IJRAS.8139
'Environment' refers to the sum total of condition, which surrounds point in space and time. The scope of the term 'Environment' has been changing and widening with the passage of time. In the primitive age, the environment consisted of only physical aspects of the earth's land, air and water as biological communities. As the time passed on, human beings extended the environment through their social, economic and political activities. Now a day's environmental issues are growing in size and complexity, threatening the survival of mankind on earth. The key environmental concerns today are climate change, global warming, natural disasters, and soil and land degradation, loss of biodiversity, air and water pollution which disturbs the balance of the living environment in a big way.

Composition of the atmosphere. Earth is warming at an unusual rate and evidence of warming is present in different forms. Climate change is perhaps the most serious environmental challenge humanity has ever faced. While the extent of climate change and its environmental and economic impacts are subject to debate, it is, nevertheless, clear that humans are altering the earth's climate in profound ways through burning fossil fuels that produce carbon dioxide, a heat-trapping gas, and from activities such as cutting of forests and agriculture that produces methane, another greenhouse gas (GHG).

\section{LITERATURE REVIEW}

The natural environment encompasses all living and nonliving things occurring naturally on Earth or some region thereof. It is an environment that encompasses the interaction of all living species.

The Primitive Age is the starting age for your civilization. The Stone Age is a broad prehistoric period during which stone was widely used to make implements with a sharp edge, a point, or a percussion surface. The period lasted roughly 3.4 million years, and ended between $6000 \mathrm{BCE}$ and $2000 \mathrm{BCE}$ with the advent of metalworking. Stone Age artifacts include tools used by humans and by their predecessor species in the genus Homo. 3 Climate change is a significant and lasting change in the statistical distribution of weather patterns over periods ranging from decades to millions of years. Certain human activities have also been identified as significant causes of recent climate change, often referred to as "global warming." The term sometimes is used to refer specifically to climate change caused by human activity, as opposed to changes in climate that may have resulted as part of Earth's natural processes. The most general definition of climate change is a change in the statistical properties of the climate system when considered over long periods of time, regardless of cause. Accordingly, fluctuations over periods shorter than a few decades, such as El Nino, do not represent climate change. 4 Biodiversity refers to the variety of life and its processes. It includes the variety of living organisms, the genetic 
differences among them, the communities and ecosystems in which they occur, and the ecological and evolutionary processes that keep them functioning, yet ever changing and adapting. 5 Santosh Kumar, "Environment and development" Yojana, May 2012, p.14 6 The term Climate is originated from Ancient Greek term klima, meaning inclination. Climate is commonly defined as the weather averaged over a long period of time. The standard averaging period is 30 years, but other periods may be used depending on the purpose. Climate also includes statistics other than the average, such as the magnitudes of day-to-day or year-to-year variations.[Glossary of Metrology- American Metrological Society.] 7 The term anthropogenic designates an effect or object resulting from human activity. The term is sometimes used in the context of pollution emissions that are produced as a result of human activities but applies broadly to all major human impacts on the environment.

Dr. Deoki Nandan, Vinod Joon, Vaishali Jaiswal, "Global Warming and the Challenges posed by Climate Change", World Focus, September 2009, p. 362

Fossil fuels are fuels formed by natural processes such as anaerobic decomposition of buried dead organisms. The age of the organisms and their resulting fossil fuels is typically millions of years, and sometimes exceeds 650 million years.

Weather is taken to mean the totality of atmospheric conditions at: any particular place and time - the instantaneous state of the atmosphere and especially those elements of it which directly affect living things. Its meaning may be extended to include exposure to radiation from the sun and to the sky, as permitted by the state of the atmosphere.

H. H. Lamb, Climate: Present, Past \& Future, Vol. 1, London: Methuen \& Co. Ltd., 1972, p. 7.

An atmosphere is a layer of gases surrounding a planet or other material body of sufficient mass that is held in place by the gravity of the body.

Extreme weather includes unusual, severe or unseasonal weather; weather at the extremes of the historical distribution - the range that has been seen in the past. The most commonly used definition of extreme weather is based on an event's climatological distribution: Extreme weather occurs only $5 \%$ or less of the time. According to climate scientists and meteorological researchers, extreme weather events have been rare. Some extreme weather events have been attributed to human-induced global warming, with a 2012 studies indicating an increasing threat from extreme weather.

\section{The Climate}

Climate is the sum total of the Weather11 experienced at a place in the course of a year and over the years. It comprises not only those conditions that can obviously be described as 'near average' or 'normal' but also the extremes and all the variations. At the simplest level, the weather is what is happening to the atmosphere 13 at any given time while climate is what would be expected to occur at any given time of the year based on statistics built up over many years. The frequently changing extreme weather events exert a major influence on the interpretation of changes in the climate; however, there may be some blurring of the distinction between weather and climate in considering specific events It follows from the definition of weather and climate; that changes in the climate constitute shifts in meteorological conditions lasting a few years or longer.

\section{LEGAL REGULATION OF GLOBAL WARMING IN INDIA}

Almost every national government in the United Nations now has a minister and a department tasked with policy on the environment, and many regional and local governments have also developed this capacity. Since 1992 the volume and quality of environmental legislation (international, national and local) has expanded hugely, and international agreements have not only raised the profile of environmental change but also begun to drive global policy change.

Domestic or national law refers to the legal system applicable to a defined territory over which a sovereign power has jurisdiction. International Law, on the other hand, regulates the conduct of the States and other international actors. Over the years domestic and international systems of law have evolved in parallel. In certain fields and regions of the world, international law has shaped and significantly contributed to the development of domestic environmental law. Yet international environmental law also reflects domestic experiences considered successful by the Community of Nations. The result is a complex relationship in which the two levels of environmental law mutually contribute to and reinforces each other.

No single country causes the problem; no single country can cure it. Only by collective community action can that tragedy be avoided.5 India is also not immune from the impact of global warming and climate change. Any sharp rise in sea level could have a considerable impact o $n$ India. The United Nations Environment Programme included India among the 27 countries that are most vulnerable to a sea level rise.

Unfortunately, India is among the countries that will suffer the most serious consequences as a result of global warming. The impact is already being felt.7 In India, climate change could represent additional pressure on ecological and socioeconomic systems that are already under stress due to rapid urbanization, industrialization, and economic development. With its huge and growing population, a 7500$\mathrm{km}$ long densely-populated and low-lying coastline, and an economy that is closely tied to its natural resource base, India is considerably vulnerable to the impacts of climate change.

\section{REFERENCE}

[1] http://www.mse.ac.in/pub/op_sankar.pdf accessed on 27th May 20145 Fred L. Morrision and Rudiger Wolfrum, International, Regional and National Environmental Law, Netherland, Kluwer Law International, 2000, p. 167

[2] H. A. C. Prasad, J. S. Kochher, "Climate Change and India: Some Major Issues and Policy Implications," Department of Economic Affairs, Ministry of Finance, Government of India, March 2009, p. 87 R. Ramchndran, "Himalayan Concerns", Frontline, March 9, 2007, p.14

[3] S Shanthakumar's Introduction to Environmental Law, 2nd edition, Nagpur, Wadhwa and Company, Reprint 2009, p. 7512918680 LR 3 HL 33013 M. C. Mehta v Union of India, AIR 1987 SC 108614 Supra note .

[4] Shyam Divan and Armin Rosencranz, Environmental Law and Policy in India, 2nd edition, New Delhi, Oxford University Press, 2001, p. 6420 Md Zafar Mahfooz Nomani, "Enviro-Constitutional Ethos in Right Duty Discourse: Towards the Creation of an Equi 